\title{
Hepatitis C virus positive diffuse large B-cell lymphomas have distinct molecular features and lack BCL2 translocations
}

Carlo Visco*,1,2 , Jinfen Wang ${ }^{3}$, Maria Chiara Tisi ${ }^{1}$, Lijuan Deng ${ }^{2}$, Emanuele S G D’Amore ${ }^{4}$, Alexandar Tzankov ${ }^{5}$, Santiago Montes-Moreno ${ }^{6}$, Karen Dybkær ${ }^{7}$, Govind Bhagat ${ }^{8}$, Eric D Hsi ${ }^{9}$, J Han van Krieken ${ }^{10}$, Maurilio Ponzoni ${ }^{11}$, Andrés J M Ferreri ${ }^{11}$, Michael B Møller ${ }^{12}$, Miguel A Piris ${ }^{6}$, L Jeffrey Medeiros ${ }^{2}$, Zijun Y Xu-Monette ${ }^{2}$ and Ken H Young ${ }^{\star 2,13}$

${ }^{1}$ Department of Hematology, San Bortolo Hospital, Via Rodolfi, 37, Vicenza 36100, Italy; ${ }^{2}$ Department of Hematopathology, The University of Texas MD Anderson Cancer Center, Houston, TX 77030, USA; ${ }^{3}$ Department of Pathology, Shanxi Cancer Hospital, Shanxi 030013, China; ${ }^{4}$ Department of Pathology, San Bortolo Hospital, Vicenza 36100, Italy; ${ }^{5}$ University Hospital, Basel 4001, Switzerland; ${ }^{6}$ Hospital Universitario Marques de Valdecilla, Santander 39008, Spain; ${ }^{7}$ Aalborg University Hospital, Aalborg 9100, Denmark; ${ }^{8}$ Columbia University Medical Center and New York Presbyterian Hospital, New York, NY 10032, USA; ${ }^{9}$ Cleveland Clinic, Cleveland, OH 44195, USA; ${ }^{10}$ Radboud University Nijmegen Medical Centre, Nijmegen 6525, The Netherlands; ${ }^{11}$ San Raffaele H. Scientific Institute, Milan 20132, Italy; ${ }^{12}$ Odense University Hospital, Odense 5000, Denmark and ${ }^{13}$ The University of Texas School of Medicine, Graduate School of Biomedical Sciences, Houston, TX 77030, USA

Background: The clinical presentation of patients with hepatitis C virus (HCV)-positive diffuse large B-cell lymphoma (DLBCL) is different from their HCV-negative counterparts, but the underlying molecular and pathological characteristics are largely under investigated. The virus has a role in lymphomagenesis, as witnessed by the curative potential of antiviral therapy in HCV-related low-grade B-cell lymphomas.

Methods: We performed a case-control study including $44 \mathrm{HCV}$-positive cases of de novo DLBCL, comparing them with $132 \mathrm{HCV}$ negative patients as controls (ratio 3 to 1). Cases and controls were matched for age, lactate dehydrogenase level and international prognostic index at presentation. Patients were studied by gene expression profiling for cell-of-origin determination and to perform differential expression analysis between groups, fluorescence in-situ hybridisation and immunohistochemistry for MYC, BCL2 and BCL6, TP53 mutations, and diagnostic specimens reviewed to exclude transformation from low-grade lymphoma.

Results: Compared to the HCV-negative controls, patients with HCV-positive de novo DLBCL had differential expression of genes that regulate innate immune response and modulate apoptotic pathways, have higher proliferative index, and lack BCL2 translocations.

Conclusions: HCV-positive DLBCL have distinct molecular and pathological features compared to the HCV-negative counterparts.

Diffuse large B-cell lymphoma (DLBCL), the most frequent type of B-cell lymphoma, accounts for about $30 \%$ of all lymphoid malignancies. This entity, which encompasses distinct morphologic, molecular, and clinicopathologic subgroups (Swerdlow et al, 2016), has been associated with hepatitis C virus (HCV) infection (Mele et al, 2003; Ennishi et al, 2010; Merli et al, 2014; Visco and Finotto, 2014). The clinical presentation of patients with $\mathrm{HCV}$-positive DLBCL is different from their $\mathrm{HCV}$-negative counterparts, since patients are older, have more frequent spleen and/or liver involvement, elevated serum lactate dehydrogenase

*Correspondence: Dr C Visco; E-mail: carlovisco@hotmail.com or Dr KH Young; E-mail: khyoung@mdanderson.org 
(LDH) and a high international prognostic index (IPI) (Ennishi et al, 2010; Merli et al, 2014; Visco and Finotto, 2014). However, the pathological characteristics of de novo DLBCL arising in patients with $\mathrm{HCV}$ infection are under-investigated. A substantial subset of HCV-positive DLBCL cases represent transformation from a pre-existing low-grade - especially marginal zone lymphoma ( $t$-DLBCL), and as such they have been postulated as being part of a multistep process that starts from type-II mixed cryoglobulinemia (MC) and the achievement of B-cell clonality (Peveling-Oberhag et al, 2013).

A role for the virus in lymphomagenesis is also suggested by the curative activity of antiviral therapy for patients with HCV-related low-grade B-cell lymphomas, even when non-interferon containing regimens are used (Arcaini et al, 2016). Such an effect implies a specific role for the virus in maintaining B-cell proliferation, although the mechanisms involved in HCV-mediated lymphomagenesis remain unknown.

In the era of DLBCL sub-classification, with cell-of-origin (COO) algorithms and fluorescence in-situ hybridisation (FISH) for BCL2 and/or MYC rearrangements having entered clinical practice, and being included in the 2016 revision of the World Health Organization (WHO) classification, we investigated the pathological characteristics of $44 \mathrm{HCV}$-positive patients with de novo DLBCL with no clinical or pathological evidence of transformation from lowgrade lymphoma, and compared them with HCV-negative DLBCL controls matched for clinical variables at presentation.

\section{MATERIALS AND METHODS}

Fifty-one newly diagnosed, previously untreated DLBCL in HCVpositive patients were organised from The International DLBCL Rituximab-CHOP Consortium Program Study. The database includes de novo DLBCL treated with standard rituximab, cyclophosphamide, doxorubicin, vincristine, and prednisolone (R-CHOP) therapy, diagnosed according to the WHO classification system and treated between 1998 and 2010. A total of 44 HCV-positive cases were included in the study based on the availability of adequate biological material for FISH, COO definition based on gene expression profile (GEP) or immunohistochemistry (IHC), complete clinical data and final diagnosis after histological review. Cases with a history or pathological evidence of previous low-grade lymphoma, or arising in a setting of congenital or acquired immunodeficiency, including patients with human immunodeficiency virus infection, were excluded.

For comparative purposes, we performed a case-control study from the entire cohort of 437 DLBCL patients that were tested at lymphoma diagnosis for serum HCV-antibodies, and selected 132 HCV-negative DLBCL patients as controls (ratio 3 to 1). Controls were matched for age, LDH level, and IPI score, which are known to represent a bias for $\mathrm{HCV}$-positive cases compared to the HCVnegative controls. This study was approved by the Institutional Review Boards of each participating centre, and the comprehensive collaborative study was approved by the Institutional Review Board at The University of Texas MD Anderson Cancer Center.

Gene expression profiling was performed on formalin-fixed, paraffin-embedded tissue extracts in all included patients using a GeneChip Human Genome U133 Plus 2.0 Array (Affymetrix, Santa Clara, CA, USA) with total RNAs as described previously (Visco et al, 2012). The CEL files were deposited in the National Center for Biotechnology Information Gene Expression Omnibus repository (GSE no. 31312). Gene expression profiling classified 104 cases as $\mathrm{GCB} / \mathrm{ABC}$ subtypes ( $19 \mathrm{HCV}+, 85 \mathrm{HCV}-$ ), and the $\mathrm{COO}$ of the remaining 72 cases was determined according to the Visco-Young (first selection) and Choi (second selection) algorithms (Visco et al, 2012). FISH was performed using BCL2 and BCL6 dual-colour, break-apart probe (07J75-001 from Vysis, Downers Grove, IL, USA) on paraffin-embedded tissue sections according to the Vysis protocol. FISH for the MYC gene was performed with a locus-specific identifier $I G H / M Y C / C E P 8$ tri-colour, dual fusion probe (DFP, 05J75-001 from Vysis) and, due to shortcomings of the former in identifying alternative (non- $I G H)$ MYC rearrangement partners, a locus-specific identifier MYC dual-colour, break-apart probe (BP, 05J91-001 from Vysis). Construction of the tissue microarrays, IHC staining procedures on tissue microarray sections, and scoring criteria for MYC and BCL2 have been described previously (Tzankov et al, 2014). Cutoffs for MYC (clone Y69; Epitomics, Burlingame, CA, USA) and BCL2 (clone 124; DAKO, Santa Clara, CA, USA) overexpression were $\geqslant 40 \%$ and $\geqslant 50 \%$, respectively, as indicated in the WHO classification (Swerdlow et al, 2016). The MIB-1 (Ki-67) expression was quantified by estimating the percentage of positive lymphoma cells among the total number of malignant lymphoid cells. Immunoreactivity was determined without knowledge of survival, clinical data, or GEP data.

Serum antibodies against $\mathrm{HCV}$ were tested at the time of lymphoma diagnosis using an enzyme-linked immunosorbent assay (ELISA; HCV 3.0; Ortho Diagnostic System, Raritan, NJ, USA) and confirmed by recombinant-based immunoblot assay (Chiron RIBA; Ortho Diagnostic System) in all 176 patients. Most HCV-positive patients (39 of 44, 89\%) were also tested for RNA Table 1. Clinical and pathological characteristics of HCV-
positive $(\mathrm{HCV}+)$ DLBCL compared to HCV-negative $(\mathrm{HCV}-)$ controls

\begin{tabular}{|c|c|c|c|}
\hline Characteristics & $\mathrm{HCV}+(n=44)$ & $\mathrm{HCV}-(n=132)$ & $P$ \\
\hline Age, years $<60$ & $23(52 \%)$ & $66(50 \%)$ & 0.69 \\
\hline Gender: male & $25(57 \%)$ & 73 (55\%) & 0.86 \\
\hline Stage: III-IV & 22 (50\%) & 78 (59\%) & 0.31 \\
\hline LDH level: elevated & 32 (73\%) & 91 (69\%) & 0.53 \\
\hline IPI score: >2 & 18/39 (46\%) & $42 / 121(35 \%)$ & 0.25 \\
\hline $\begin{array}{l}\text { GCB/ABC by GEP } \\
\text { GCB } \\
\text { ABC } \\
\text { UNCL }\end{array}$ & $\begin{array}{l}9 / 19(47 \%) \\
9 / 19(47 \%) \\
1 / 19(6 \%)\end{array}$ & $\begin{array}{c}37 / 85(44 \%) \\
41 / 85 \text { (48\%) } \\
7 / 85(8 \%)\end{array}$ & 0.89 \\
\hline $\begin{array}{l}\text { GCB/ABC by IHC } \\
\text { GCB } \\
\text { Non-GCB }\end{array}$ & $\begin{array}{l}18 / 40(45 \%) \\
22 / 40(55 \%)\end{array}$ & $\begin{array}{l}56 / 122(46 \%) \\
69 / 122(54 \%)\end{array}$ & 0.92 \\
\hline CD37 expression: + & 13/32 (41\%) & 55/116 (47\%) & 0.54 \\
\hline MYC translocation: + & $2 / 31(6 \%)$ & $5 / 103(5 \%)$ & 0.72 \\
\hline BCL2 translocation: + & 0/33 (0\%) & 23/123 (19\%) & 0.004 \\
\hline BCL6 translocation: + & $5 / 30(17 \%)$ & 24/101 (24\%) & 0.49 \\
\hline Double hit (MYC/BCL2) & $0 / 26(0 \%)$ & 2/99 (2\%) & 0.46 \\
\hline Double hit (MYC/BCL6) & $1 / 23(4 \%)$ & $1 / 81(1 \%)$ & 0.21 \\
\hline TP53 mutations: + & $3 / 21(14 \%)$ & $23 / 84(27 \%)$ & 0.21 \\
\hline $\begin{array}{l}\mathrm{BCL} 2 \text { protein } \\
\text { expression: } \geqslant 50 \%\end{array}$ & $17 / 38$ (45\%) & $83 / 123(67 \%)$ & 0.01 \\
\hline $\begin{array}{l}\text { MYC protein } \\
\text { expression: } \geqslant 40 \%\end{array}$ & 21/41 (51\%) & 66/125 (53\%) & 0.86 \\
\hline Double Expressors (DEL) & $8 / 36(22 \%)$ & 45/120 (38\%) & 0.08 \\
\hline MIB-1 expression: > 70\% & $18 / 27(67 \%)$ & $35 / 84(42 \%)$ & 0.02 \\
\hline IgA expression: $100 \%$ & $3 / 21(14 \%)$ & $1 / 82(1 \%)$ & 0.005 \\
\hline IgG expression: $100 \%$ & $6 / 21(29 \%)$ & $6 / 82(7 \%)$ & 0.006 \\
\hline IgM expression: $100 \%$ & $9 / 21(43 \%)$ & $22 / 82(27 \%)$ & 0.15 \\
\hline \multicolumn{4}{|c|}{$\begin{array}{l}\text { Abbreviations: } A B C=\text { activated } B \text {-cell type; } D E L=\text { double expressors lymphoma for } \\
B C L 2 \text { 'and } M Y C \text { proteins; } G C B=\text { germinal centre } B-c e l l \text { type; } H C V=\text { hepatitis } C \text { virus } \\
\text { Ig = immunoglobulins; } I H C=\text { immunohistochemistry; } I P I=\text { international prognostic index } \\
L D H=\text { lactate dehydrogenase; MIB-1 = Mindbomb } E 3 \text { ubiquitin protein ligase } 1 \text { (Ki-67), } \\
\text { UNCL= unclassifiable. Significant values are shown in bold. }\end{array}$} \\
\hline
\end{tabular}


sequences of $\mathrm{HCV}$ by reverse transcriptase polymerase chain reaction using primers for the $5^{\prime}$ noncoding region, and all resulted positive. Virus genotype was rarely available (5 out of 44).

The non-parametric Mann-Whitney test and Fisher exact test were used to compare quantitative and categorical variables across groups of patients, respectively. Statistical analyses were performed using Stata 12.1 software.

\section{RESULTS}

The median age of $\mathrm{HCV}$-positive cases (59 years) was similar to HCV-negative controls (61 years, $P=0.44$ by Mann-Whitney test), as were all main clinical parameters. This was a logical consequence of our match of patients by means of age, $\mathrm{LDH}$, and IPI risk groups at lymphoma diagnosis (Table 1). No difference in terms of COO was found between HCV-positive and -negative patients, both by GEP and IHC. Surprisingly, BCL2 translocation was not identified in any of the $33 \mathrm{HCV}$-positive DLBCL patients assessed, but was present in 23 of $123 \mathrm{HCV}$-negative controls $(19 \%, P=0.004)$. Accordingly, BCL2 protein was significantly less expressed in $\mathrm{HCV}$-positive cases compared to HCV-negative controls, although double expressor cases (MYC and BCL2) were equally represented $(p=0.08)$. No significant difference was found in terms of BCL2 gene amplification between HCV-positive cases and controls (6 and $11 \%$, respectively, $P=0.43$ ). Translocations of MYC and BCL6 genes were equally represented in the HCV-positive and control groups (Table 1). Among other analysed IHC variables we found that $\mathrm{HCV}$-positive cases had significantly higher MIB-1 (Ki-67) expression (median expression value 80 vs $70 \%, P=0.04$ by Mann-Whitney test), and did express immunoglobulins (IgA and IgG) more frequently than the HCVnegative counterparts (Table 1). No difference in overall survival and/ or progression-free survival was observed between the HCV-positive cases and controls (data not shown).
By GEP, we found 23 genes that were differentially expressed between $\mathrm{HCV}$-positive cases and HCV-negative controls without $B C L 2$ translocation (Figure 1). Among them, the suppressor of IKBKE 1 (SIKE-1), which modulates the innate immunity response by suppressing virus-triggered activation pathways was upregulated, and the C-Maf inducing protein (CMIP) gene, which encodes a protein that plays a role in T-cell signalling pathway was downregulated in HCV-positive cases. Fas apoptosis inhibitory molecule (FAIM) and cyclin-G2 (CCNG2) genes, that regulate $\mathrm{B}$-cell signalling and differentiation by protecting against apoptosis were upregulated in HCV-positive cases.

\section{DISCUSSION}

We conclude that HCV-positive de novo DLBCL cases retain molecular features that differ from their HCV-negative DLBCL counterparts. The absence of BCL2 gene translocations in this series, together with a consistently lower incidence of BCL2 protein expression, points to the existence of different mechanisms that drive oncogenesis in these patients. This is of interest because a high prevalence of $\mathrm{t}(14 ; 18)(\mathrm{q} 32 ; \mathrm{q} 21) / I G H-B C L 2$ associated with increased BCL2 expression has been detected in peripheral blood mononuclear cells of patients with $\mathrm{HCV}$ infection or $\mathrm{MC}$ (Zuckerman et al, 2001), although no study is available in DLBCL.

The data we present suggest that BCL2-translocation-positive cells in the blood do not appear to be precursors that are important for subsequent steps of lymphomagenesis, at least for DLBCL (Zuckerman et al, 2001; Mollejo et al, 2014). One may speculate that BCL2 aberrations are involved in the onset of initial B-cell proliferations, such as $\mathrm{MC}$, but the pathogenesis of $\mathrm{HCV}$ associated DLBCL is driven by alterations of different pathways (i.e., NOTCH) (Peveling-Oberhag et al, 2013; Visco and Finotto, 2014; Arcaini et al, 2015). Indeed, modulation of the apoptotic
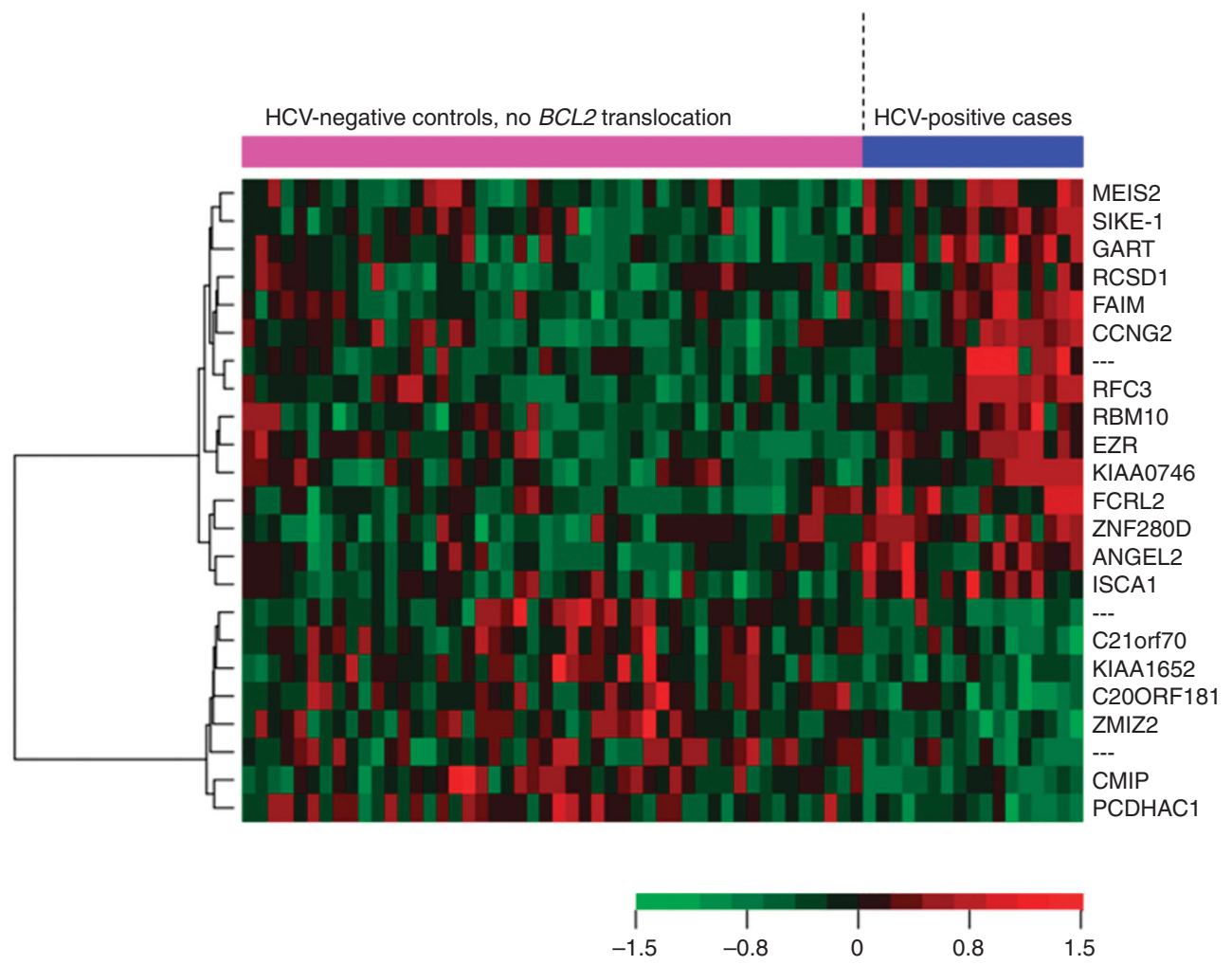

Figure 1. Heat map of hierarchical clustering of GEP on DLBCL patients, comparing HCV-positive patients (blue), with HCV-negative controls without BCL2 translocation (purple). With a false discovery rate (FDR) threshold of 0.20 there were 23 significant transcripts corresponding to the gene list on the right. 
response by degradation of $B C L 2$ interacting domain (Bid) is one strategy used by HCV to escape immune surveillance, neutralise host defences, and establish chronic infection (Simonin et al, 2009). Accordingly, FAIM and CCNG2 genes were upregulated in the $\mathrm{HCV}$-positive cases compared to $\mathrm{HCV}$-negative controls without BCL2 translocation (Figure 1). Also notably, the CMIP, which plays a role in T-cell signalling, was downregulated, and SIKE-1, which suppresses virus-triggered interferon activation, was upregulated, supporting the importance of immune regulation pathways in the pathogenesis of HCV-positive DLBCL.

The data presented differ from events in HCV-related hepatocellular carcinoma, where $\mathrm{HCV}$ infection is related to mutations of the TP53 gene (Teramoto et al, 1994). In this study TP53 was equally mutated in HCV-positive and -negative lymphomas. Conversely, we found a bias of HCV-positive patients in terms of higher tumour proliferation (MIB1 expression) and immunoglobulin expression by the tumour (IgG and IgA), consistent with a late, secretory, post-germinal centre COO, a feature more commonly observed in virus-related DLBCL (Gloghini et al, 2013). Further studies, including independent validation data sets are needed to confirm our findings and to confirm our preliminary observations.

The literature has paid relatively little attention to HCV-positive DLBCL as compared with HCV-positive low-grade lymphomas (Mele et al, 2003; Peveling-Oberhag et al, 2013; Visco and Finotto, 2014; Arcaini et al, 2016). A recent study has shown NOTCH pathway mutations in 25\% HCV-positive DLBCL. Importantly, NOTCH pathway mutations were found to be restricted to HCVpositive DLBCL, although they were associated with the coexistence of a low-grade component in the diagnostic biopsy specimen (Arcaini et al, 2015). These data support the notion that a subgroup of DLBCL arising in subjects carrying HCV infection represent transformation of an underlying clinically unrecognised indolent lymphoma. Our study, which included patients without transformation from low-grade lymphoma, provides information likely helpful in further pathological exploration of these tumours.

\section{ACKNOWLEDGEMENTS}

This study was supported by the National Institutes of Health/ National Cancer Institute grants R01CA138688 and 1RC1CA146299 to KHY. The study is also partially supported by P50CA136411 and P50CA142509 and the MD Anderson Cancer Center Support Grant CA016672.

CONFLICT OF INTEREST

The authors declare no conflict of interest.

\section{REFERENCES}

Arcaini L, Besson C, Frigeni, Fontaine H, Goldaniga M, Casato M, Visentini M, Torres HA, Loustaud-Ratti V, Peveling-Oberhag J, Fabris P, Rossotti R, Zaja F, Rigacci L, Rattotti S, Bruno R, Merli M, Dorival C, Alric L, Jaccard A, Pol S, Carrat F, Ferretti VV, Visco C, Hermine O (2016) Interferon-free antiviral treatment in B-cell lymphoproliferative disorders associated with hepatitis $\mathrm{C}$ virus infection. Blood 128: 2527-2532.

Arcaini L, Rossi D, Lucioni M, Nicola M, Bruscaggin A, Fiaccadori V, Riboni R, Ramponi A, Ferretti VV, Cresta S, Casaluci GM, Bonfichi M, Gotti M, Merli M, Maffi A, Arra M, Varettoni M, Rattotti S, Morello L, Guerrera ML, Sciarra R, Gaidano G, Cazzola M, Paulli M (2015) The NOTCH pathway is recurrently mutated in diffuse large B-cell lymphoma associated with hepatitis C virus infection. Haematologica 100: 246-252.
Ennishi D, Maeda Y, Niitsu N, Kojima M, Izutsu K, Takizawa J, Kusumoto S, Okamoto M, Yokoyama M, Takamatsu Y, Sunami K, Miyata A, Murayama K, Sakai A, Matsumoto M, Shinagawa K, Takaki A, Matsuo K, Kinoshita T, Tanimoto M (2010) Hepatic toxicity and prognosis in hepatitis $\mathrm{C}$ virus infected patients with diffuse large B-cell lymphoma treated with rituximab-containing chemotherapy regimens: a Japanese multicenter analysis. Blood 116: 5119-5125.

Gloghini A, Dolcetti R, Carbone A (2013) Lymphomas occurring specifically in HIV-infected patients: from pathogenesis to pathology. Semin Cancer Biol 23: 457-467.

Mele A, Pulsoni A, Bianco E, Musto P, Szklo A, Sanpaolo MG, Iannitto E, De Renzo A, Martino B, Liso V, Andrizzi C, Pusterla S, Dore F, Maresca M, Rapicetta M, Marcucci F, Mandelli F, Franceschi S (2003) Hepatitis $\mathrm{C}$ virus and B-cell non-Hodgkin lymphomas: an Italian multicenter case-control study. Blood 102: 996-999.

Merli M, Visco C, Spina M, Luminari S, Ferretti VV, Gotti M, Rattotti S, Fiaccadori V, Rusconi C, Targhetta C, Stelitano C, Levis A, Ambrosetti A, Rossi D, Rigacci L, D’Arco AM, Musto P, Chiappella A, Baldini L, Bonfichi M, Arcaini L (2014) Outcome prediction of diffuse large B-cell lymphomas associated with hepatitis $C$ virus infection: a study on behalf of the Fondazione Italiana Linfomi. Haematologica 99: 489-496.

Mollejo M, Menárguez J, Guisado-Vasco P, Bento L, Algara P, Montes-Moreno S, Rodriguez-Pinilla MS, Cruz MA, Casado F, Montalbán C, Piris MA (2014) Hepatitis C virus-related lymphoproliferative disorders encompass a broader clinical and morphological spectrum than previously recognized: a clinicopathological study. Mod Pathol 27: 281-293.

Peveling-Oberhag J, Arcaini L, Hansmann ML, Zeuzem S (2013) Hepatitis C-associated B-cell non-Hodgkin lymphomas. Epidemiology, molecular signature and clinical management. J Hepatol 59: 169-177.

Simonin Y, Disson O, Lerat H, Antoine E, Binamé F, Rosenberg AR, Desagher S, Lassus P, Bioulac-Sage P, Hibner U (2009) Calpain activation by hepatitis $\mathrm{C}$ virus proteins inhibits the extrinsic apoptotic signaling pathway. Hepatology 50: 1370-1379.

Swerdlow SH, Campo E, Pileri SA, Harris NL, Stein H, Siebert R, Advani R, Ghielmini M, Salles GA, Zelenetz AD, Jaffe ES (2016) The 2016 revision of the World Health Organization classification of lymphoid neoplasms. Blood 127: 2375-2390.

Teramoto T, Satonaka K, Kitazawa S, Fujimori T, Hayashi K, Maeda S (1994) p53 gene abnormalities are closely related to hepatoviral infections and occur at a late stage of hepatocarcinogenesis. Cancer Res 54: 231-235.

Tzankov A, Xu-Monette ZY, Gerhard M, Visco C, Dirnhofer S, Gisin N, Dybkaer K, Orazi A, Bhagat G, Richards KL, Hsi ED, Choi WW, van Krieken JH, Ponzoni M, Ferreri AJ, Ye Q, Winter JN, Farnen JP, Piris MA, Møller MB, You MJ, McDonnell T, Medeiros LJ, Young KH (2014) Rearrangements of MYC gene facilitate risk stratification in diffuse large B-cell lymphoma patients treated with rituximab-CHOP. Mod Pathol 27: 958-971.

Visco C, Finotto S (2014) Hepatitis C virus and diffuse large B-cell lymphoma: pathogenesis, behavior and treatment. World J Gastroenterol 20: 11054-11061.

Visco C, Li Y, Xu-Monette ZY, Miranda RN, Green TM, Tzankov A, Wen W, Liu WM, Kahl BS, d'Amore ES, Montes-Moreno S, Dybkær K, Chiu A, Tam W, Orazi A, Zu Y, Bhagat G, Winter JN, Wang HY, O’Neill S, Dunphy CH, Hsi ED, Zhao XF, Go RS, Choi WW, Zhou F, Czader M, Tong J, Zhao X, van Krieken JH, Huang Q, Ai W, Etzell J, Ponzoni M, Ferreri AJ, Piris MA, Møller MB, Bueso-Ramos CE, Medeiros LJ, Wu L, Young KH (2012) Comprehensive gene expression profiling and immunohistochemical studies support application of immunophenotypic algorithm for molecular subtype classification in diffuse large B-cell lymphoma: a report from the International DLBCL Rituximab-CHOP Consortium Program Study. Leukemia 26: 2103-2113.

Zuckerman E, Zuckerman T, Sahar D, Streichman S, Attias D, Sabo E, Yeshurun D, Rowe J (2001) BCL2 and immunoglobulin gene rearrangement in patients with HCV infection. Br J Haematol 112: 364-369.

This work is published under the standard license to publish agreement. After 12 months the work will become freely available and the license terms will switch to a Creative Commons AttributionNonCommercial-Share Alike 4.0 Unported License. 